\title{
Macrophylloflavone: A New Biflavonoid from Garcinia macrophylla Mart. (Clusiaceae) for Antibacterial, Antioxidant, and Anti-Type 2 Diabetes Mellitus Activities
}

\author{
Hawa Purnama Celala Ary Cane, ${ }^{1}$ Nurdin Saidi, ${ }^{2}$ Mustanir Yahya, ${ }^{2}$ Darusman Darusman, ${ }^{3}$ \\ Erlidawati Erlidawati, ${ }^{4}$ Safrida Safrida, ${ }^{5}$ and Musri Musman ${ }^{4}{ }^{4}$
}

${ }^{1}$ Graduate School of Mathematics and Applied Sciences, Universitas Syiah Kuala, Banda Aceh 23111, Indonesia

${ }^{2}$ Department of Chemistry, Universitas Syiah Kuala, Banda Aceh 23111, Indonesia

${ }^{3}$ Department of Soil Science, Universitas Syiah Kuala, Banda Aceh 23111, Indonesia

${ }^{4}$ Department of Chemistry Education, Universitas Syiah Kuala, Banda Aceh 23111, Indonesia

${ }^{5}$ Department of Biology Education, Universitas Syiah Kuala, Banda Aceh 23111, Indonesia

Correspondence should be addressed to Musri Musman; musrimusman@unsyiah.ac.id

Received 24 January 2020; Revised 14 April 2020; Accepted 24 April 2020; Published 12 May 2020

Academic Editor: Alessandro Sacchetti

Copyright (C) 2020 Hawa Purnama Celala Ary Cane et al. This is an open access article distributed under the Creative Commons Attribution License, which permits unrestricted use, distribution, and reproduction in any medium, provided the original work is properly cited.

\begin{abstract}
Investigations of antibacterial, antioxidant, and anti-type 2 diabetes mellitus activities have been carried out on Garcinia macrophylla Mart. plant extract fractions. An isolate from a fraction of ethyl acetate extract was characterized with spectroscopic data. A new biflavonoid compound was found to have a skeleton of 5,7,4 $, 5^{\prime \prime}, 7^{\prime \prime}, 3^{\prime \prime \prime}, 4^{\prime \prime \prime}$-heptahydroxyflavanone[3-6"] flavones which was named macrophylloflavone (1). The compound was evaluated for its antibacterial activity against Escherichia coli ATCC 25922 and Staphylococcus aureus ATCC 25923 with cephazolin as a positive control, antioxidant assay against 2,2 diphenyl-1picrylhydrazyl (DPPH) with ascorbic acid as the positive control, and anti-type 2 diabetes mellitus treatment with metformin as a positive control. The biflavonoid compound exhibited a good inhibition for bacteria and free radical DPPH. Furthermore, biflavonoid compound treatment on the diabetic rats suggested its ability to decrease the blood glucose level. This study provided evidence that the plant has antibacterial, antioxidant, and antidiabetic properties.
\end{abstract}

\section{Introduction}

Degenerative diseases contribute the most number of world's mortalities and morbidities. According to many studies, the main factor causing the degenerative diseases is free radicals, which are actively produced through human body metabolic process [1-4]. Diabetes mellitus is an example of degenerative diseases which is infamous for the death of 1.6 million people worldwide in 2016. The disease is believed to be the main cause due to a lack of insulin secretion by the pancreas or metabolic disorders when blood glucose levels are higher (hyperglycemia) than normal levels [5]. Recent studies also found that people with the disease are more susceptible to dermatologic infections, such as staphylococcal follicular skin infections, erysipelas, and cellulitis. This is made worse by the fact that the human body is vulnerable to pathogenic bacteria, even when we carry out our daily routine $[6,7]$. It leads to a situation where patients take many kinds of medicines. To deal with the bacterial disease problems, many people rely on antibiotics. However, the rise of antibiotic-resistant bacteria has grown a concern to find the alternative for antibiotics [8]. In addition, synthetic drugs are often used for maintenance-free radical and diabetes mellitus, not to mention the fact that synthetic drug intake can exert multiple adverse effects on health $[9,10]$.

As an alternative, this study proposed the use of ethnomedicinal plants which have antibacterial, antioxidant, and antidiabetic activities [11, 12]. Plant-based medicines are famous for their low toxicity, minimal side effects, and high availability. The plants have potential medicinal uses 
due to their bioactive secondary metabolites, including the flavonoids [13-15]. Multiple studies have reported the benefits of flavonoids in overcoming various infectious and degenerative diseases [16-19].

Garcinia is a plant genus that is known to produce flavonoids in major quantities [20]. In Gayo Lues, a regency in Aceh Province, Indonesia, the local people have used Garcinia macrophylla Mart. stem barks as traditional medicine to combat the bacteria and free radicals. $G$. macrophylla had been studied for its pharmacology on inflammation, analgesic, microbial infection, and cancer [21]. However, the flavonoids in the G. macrophylla have not been thoroughly discussed. To the best of the authors' knowledge, this is the first report on the antibacterial, antioxidant, and anti-type 2 diabetic activities of the new biflavonoid extracted from G. macrophylla (Clusiaceae).

\section{Materials and Methods}

2.1. Materials. The instruments used in this research included rotary evaporator (Heidolph Laborota 4003 Control), UV-Vis (Shimadzu), FTIR (Prestige 21 Shimadzu), autoclave (Llenado-Filling), NMR (Agilent $500 \mathrm{MHz}$ ), shaker (Edmund Buhler D-7454 Bodelshausen), spectrophotometer (Spectro 20 D Plus Spectrophotometer), incubator (Lab-Line Instruments Ultra-Clean “100”), MultiCheck Nesco (Nesco Medlab, Indonesia), biological microscope (MEIJI TECHNO), Leica 2235 rotary microtome, electrothermal paraffin section mounting bath, SLEE paraffin embedding set, lamp ultraviolet (UV Laborgerate Vetter GMBH, Wiesloch), and MS (Shimadzu GCMS-QP 2010 Ultra).

The bacteria (Escherichia coli ATCC 25922 and Staphylococcus aureus ATCC 25923) were obtained from the Microbiology Laboratory, Faculty of Pharmacy at the University of Sumatera Utara (USU), Medan, Indonesia. The materials included in this research were Lactose Broth (LB), ascorbic acid 99.7\%, distilled water, silica gel G 60 (Merck), Muller Hinton Agar (MHA), n-hexane 96\%, dimethyl sulfoxide (DMSO) $99.9 \%$, ethyl acetate $96 \%, \mathrm{NaCl}$, methanol $96 \%$, dichloromethane $96 \%$, paper disc $(6 \mathrm{~mm})$, cephazolin $30 \mu \mathrm{g}$ (disc $6 \mathrm{~mm}$ ), strip test Nesco, metformin, glucose monohydrate p.a., Whatman filter paper grade 41, 2,2diphenyl-1-picrylhydrazyl (DPPH), Neutral Buffered Formalin (NBF) 10\%, ethanol (70\%, 80\%, 90\%, 96\%, and absolute), hematoxylin eosin, TLC preparative silica gel 60 $\mathrm{F}_{254}$, deuterated methanol $\left(\mathrm{CD}_{3} \mathrm{OD}\right)$, methanol $99.9 \%$, and $\mathrm{FeCl}_{3}$.

2.2. Sample Collection. G. macrophylla stem bark sample was collected from Gayo Lues Regency, Aceh Province, Indonesia $\left(4^{\circ} 3^{\prime} 10,56^{\prime \prime} \mathrm{N} 97^{\circ} 24^{\prime} 18,15^{\prime \prime} \mathrm{E}\right)$, in September 2016. It was identified by a botanist of Research Center for Biology at Indonesian Institute of Sciences (LIPI), Bogor, Indonesia. The specimen voucher was labeled as $5 /$ Medang Kandis. In Indonesia, the plant is called Kandis Gajah [22].

2.3. Extraction, Isolation, and Elucidation. The sample was chopped and dried. $2.5 \mathrm{~kg}$ of the dried sample was extracted with maceration using methanol 96\%. All filtrates obtained were concentrated with the rotary evaporator. The methanol extract $(212.6 \mathrm{~g})$ was sequentially partitioned with $96 \% n$ hexane $(500 \mathrm{~mL})$ solvent and $96 \%$ ethyl acetate $(1,500 \mathrm{~mL})$ solvent in a separating funnel. The solvent of the fraction was evaporated to obtain the $n$-hexane fraction ( $10.5 \mathrm{~g})$, the ethyl acetate fraction $(101.4 \mathrm{~g})$, and the methanol fraction (100.4 g), respectively.

An ethyl acetate extract fraction (50 g) was isolated with column chromatography $(\phi=5 \mathrm{~cm})$. Isolation was conducted using silica gel G $60 \mathrm{~F}(500 \mathrm{~g})$ as stationary phase and dichloromethane-ethyl acetate as mobile phase, by the increase of polarity. The addition of polarity in the chromatography process was maintained until dichloromethane-ethyl acetate ratio reached 0:100 (v/v). Afterward, the purification to yield pure isolate was performed with rechromatography, preparative TLC, and recrystallization. A total of $60 \mathrm{mg}$ of the pure isolate was elucidated by $1 \mathrm{D}-\mathrm{NMR}(1 \mathrm{H}$ and $13 \mathrm{C}), 2 \mathrm{D}-\mathrm{NMR}$ (HSQC and HMBC), GC-MS, FTIR, and UV-Vis spectrophotometers. The final product of this process was a biflavonoid compound $\mathbf{1}$.

2.4. Antioxidant Assay. A free radical scavenging experiment was accomplished by modifying the DPPH reduction method [23]. This experiment was carried out using $99.9 \%$ methanol as a blank. DPPH $0.1 \mathrm{mM}$ of $11 \mathrm{~mL}$ was prepared (0.0005 grams of DPPH crystal in $11 \mathrm{~mL}$ of $99.9 \%$ methanol solvent). A negative control was formulated by adding $3 \mathrm{~mL}$ of $99.9 \%$ methanol solvent to $1 \mathrm{~mL}$ of DPPH $0.1 \mathrm{mM}$. A positive control (ascorbic acid) and tested compound (compound 1) were prepared in stock beforehand with concentrations of $100 \mathrm{ppm}$ ( 0.001 grams in $10 \mathrm{~mL}$ of $99.9 \%$ methanol solvent), respectively. The positive control and the tested compound stock solutions were diluted to varying doses of 2, 4, 6, 8, and 10 (ppm), respectively. A total of $1 \mathrm{~mL}$ of $0.1 \mathrm{mM}$ DPPH solution was pipetted and added to $3 \mathrm{~mL}$ variation of the positive control and the tested compound doses, respectively. All solutions were incubated under conditions at room temperature in a dark room for 30 minutes, and the process of measuring absorbance was continued at a wavelength of $517 \mathrm{~nm}$ with a spectrophotometer. All absorbance values were calculated for percent inhibition and $\mathrm{IC}_{50}$.

2.5. Antibacterial Assay. A subculture method was performed to inoculate each strain of bacteria [24]. A LB medium of $20 \mathrm{~mL}$ was prepared for each bacterium. A bacterium was taken from agar media stock and added to each LB medium. The bacterium in LB media was regenerated overnight at $37^{\circ} \mathrm{C}$. The fresh bacterium was suspended in $10 \mathrm{~mL} \mathrm{NaCl} 0.85 \%$ until an absorbance reached $0.5-0.8$ (in order to afford $1 \times 10^{8} \mathrm{CFU} / \mathrm{mL}$ ) on $\mathrm{OD}_{600}$ by a spectrophotometer [25].

The antibacterial activities were carried out by the disc diffusion method [26]. $20 \mathrm{~mL}$ of MHA solution was poured into a Petri dish glass (size of $100 \times 15 \mathrm{~mm}$ ). Furthermore, fresh E. coli and S. aureus were smeared over agar media of the Petri dish. The paper discs containing the compound $\mathbf{1}$ 
(doses of $30 \mu \mathrm{g} / \mathrm{mL}, 60 \mu \mathrm{g} / \mathrm{mL}$, and $120 \mu \mathrm{g} / \mathrm{mL}$ ), the positive control of cephazolin, and the negative control of DMSO were placed on the top of the growth media. Incubation was carried out at $37^{\circ} \mathrm{C}$ for 24 hours. The inhibition zones were measured by a caliper in millimeters $(\mathrm{mm})$ as an indication of antibacterial activity.

2.6. Antidiabetic Assay. Rattus norvegicus rats (150-250 g) aged 2.5-3.0 months in healthy conditions were divided into 5 groups with 5 rats in each group. All rats were adapted for 7 days by giving pellets as food and distilled water as drinks in the cage [27]. Each rat for the experiment was given a group code, and its blood sugar level was checked initially after 7 days of adaptation (referred to as pretreatment). The group code was confirmed as follows: the negative control group was coded with $\mathrm{B}$, the positive control group was given the metformin drug coded with B1, and the groups were given the compound 1 with varying doses of 6,7 , and $8(\mu \mathrm{g} / \mathrm{kg}$ body weight) given their respective codes B2, B3, and B4. Furthermore, a glucose monohydrate was injected with a dose of $150 \mathrm{mg} / \mathrm{kg}$ body weight in all rats [28]. After 7 days of the glucose monohydrate administration, blood glucose levels were measured again in these rats (referred to as diabetic blood). A diabetic rat was given oral treatment in each group once a day, namely, group B0 (given the distilled water), B1 (given the metformin), B2 (given the compound 1 at dose of $6 \mu \mathrm{g} / \mathrm{kg}$ body weight), B3 (given the compound $\mathbf{1}$ at dose of $7 \mu \mathrm{g} / \mathrm{kg}$ body weight), and B4 (given the compound $\mathbf{1}$ at dose of $8 \mu \mathrm{g} / \mathrm{kg}$ body weight). The blood glucose levels were checked every 7 days until they became normal again (referred to as posttreatment). Selected rats from each group at the end of the treatment were sacrificed for taking kidney, pancreatic, and liver organs in order to do histopathological analysis.

2.7. Histopathological Studies. The kidney, pancreas, and liver organs in the treatment rats (various group codes as B0, $\mathrm{B} 1, \mathrm{~B} 2, \mathrm{~B} 3$, and B4) and normal rats without the treatment (blank control with code A) were targeted for histopathological examination. The organs were soaked for 7 days into a 10\% NBF before histopathology [29]. Histopathology was carried out by staining organs that have been sliced with hematoxylin-eosin dyes and placed on glass preparation. The glass preparation organs were observed using a biological microscope to determine cell performance in the kidneys, pancreas, and liver of rats.

2.8. Statistical Analysis. The obtained data were handled through Microsoft Excel 2010 software (Microsoft Corp., Redmond, WA). All data were presented as mean$s \pm$ standard deviation in the assay. The $\mathrm{IC}_{50}$ value in the antioxidant assay was calculated based on linear regression analysis of plot concentration variation $(\mu \mathrm{g} / \mathrm{mL})$ to inhibition (\%). Two-way ANOVA was used for the study of antidiabetic assay using GraphPad software Prism 7 (GraphPad Software, Inc., San Diego, California, USA). Matching between groups was carried out by Tukey's post hoc examination. $p$ values $<0.05$ were considered significantly different. The one-way ANOVA for the study of histopathological data was run by R 3.6.2 software.

\section{Results and Discussion}

3.1. Structure Elucidation. The substance $\mathbf{1}$ isolated from the ethyl acetate fraction of the G. macrophylla stem barks possessed yellow solid appearance. UV spectrum gave the $\lambda_{\max }$ of $\mathrm{MeOH}$ at $260.0 \mathrm{~nm}$ and $274.0 \mathrm{~nm}$, ascribed to the presence of $\pi-\pi *$ electron excitation, which was typical for chromophore moiety with conjugated double bonding systems $-\mathrm{C}=\mathrm{C}-\mathrm{C}=\mathrm{C}$ - on the aromatic rings. Meanwhile, the $\lambda_{\max }$ at $331.2 \mathrm{~nm}$ and $355.0 \mathrm{~nm}$ indicated the $\mathrm{n}-\pi *$ electron excitation (i.e., presence of heteroatom or conjugated carbonyl $-\mathrm{C}=\mathrm{C}-\mathrm{C}=\mathrm{O}$ ).

The FTIR spectrum of compound $\mathbf{1}$ which was subjected directly to the GC-MS instrument exhibited the specific absorption signals corresponding to particular functional groups at respective wavenumber; they were $3252-3387 \mathrm{~cm}^{-1}$ $(-\mathrm{OH}) ; \quad 2924 \mathrm{~cm}^{-1}$ (C-H aliphatic), $1643 \mathrm{~cm}^{-1}$ and $1607 \mathrm{~cm}^{-1}(\mathrm{C}=\mathrm{O}), \quad 1514 \mathrm{~cm}^{-1}$ and $1452 \mathrm{~cm}^{-1}(\mathrm{C}=\mathrm{C}$ aromatic); $1368 \mathrm{~cm}^{-1}$ and $1261 \mathrm{~cm}^{-1}$ (C-C aliphatic); and $1165 \mathrm{~cm}^{-1}, 1088 \mathrm{~cm}^{-1}$, and $1049 \mathrm{~cm}^{-1}$ (C-O). Two fragmentations were present in GC-MS data, at $\mathrm{m} / z$ [M-H] 270 $\left(\mathrm{C}_{15} \mathrm{H}_{11} \mathrm{O}_{5}\right)$ and $284\left(\mathrm{C}_{15} \mathrm{H}_{8} \mathrm{O}_{6}\right)$.

The ${ }^{1} \mathrm{H}-\mathrm{NMR}$ spectrum of $\mathbf{1}$ suggested the presence of 13 protons: ten aromatic, two aliphatic, and one olefinic. The aromatic protons appeared at the $\delta_{\mathrm{H}}(\mathrm{ppm}) 5.96(1 \mathrm{H}, \mathrm{d}$, $J=2.15 \mathrm{~Hz}), \quad 5.98(1 \mathrm{H}, \mathrm{d}, J=2.15 \mathrm{~Hz}), 7.07 \quad(1 \mathrm{H}, \mathrm{d}$, $J=8.30 \mathrm{~Hz}), 6.64(1 \mathrm{H}, \mathrm{d}, J=8.05 \mathrm{~Hz}), 6.43(1 \mathrm{H}, \mathrm{d}$, $J=8.10 \mathrm{~Hz}), 7.10(1 \mathrm{H}, \mathrm{d}, J=8.25 \mathrm{~Hz}), 6.25(1 \mathrm{H}, \mathrm{s}), 7.33(1 \mathrm{H}$, $\mathrm{m}), 6.91(1 \mathrm{H}, \mathrm{d}, J=8.35 \mathrm{~Hz})$, and $7.29(1 \mathrm{H}, \mathrm{d}, J=8.40 \mathrm{~Hz})$. Meanwhile, the aliphatic protons were characterized at the $\delta_{\mathrm{H}}(\mathrm{ppm}) 5.75(1 \mathrm{H}, \mathrm{d}, J=11.90 \mathrm{~Hz})$ and $4.83(1 \mathrm{H}, \mathrm{d}$, $J=11.95 \mathrm{~Hz}$ ), and the olefinic proton was detected at $\delta_{\mathrm{H}}$ (ppm) 6.39 (1H, s).

The ${ }^{13} \mathrm{C}-\mathrm{NMR}$ spectrum of $\mathbf{1}$ displayed the 30 carbon atoms with the characteristics of two carbonyl carbons, 15 quaternary carbons, and 13 tertiary carbons. The carbonyl carbon signals were detected at the $\delta_{\mathrm{C}}(\mathrm{ppm}) 197.91$ and 183.83. The signals of quaternary carbon appeared at the $\delta_{\mathrm{C}}$ (ppm) 164.81, 165.73, 168.19, 103.19, 130.49, 158.81, 165.73, $157.37,102.02,163.31,162.53,104.95,123.34,146.79$, and 150.94. The tertiary carbons were confirmed at the $\delta_{\mathrm{C}}(\mathrm{ppm})$ $82.72,50.84,97.43,96.42,129.24,115.61,115.54,129.24$, $103.37,99.83,114.17,116.84$, and 120.55 . Indeed, the DEPT data also confirmed the presence of tertiary and quaternary carbons.

The HMBC cross-peak between protons and carbons demonstrated two aliphatic protons correlation to several carbons, i.e., $\mathrm{H}-2\left(\delta_{\mathrm{H}} 5.75 \mathrm{ppm}, 1 \mathrm{H}, \mathrm{d}, J=11.90 \mathrm{~Hz}\right)$ to C-4

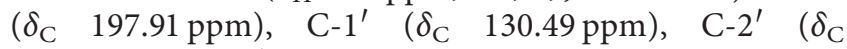
$129.24 \mathrm{ppm}), \mathrm{C}-6^{\prime}\left(\delta_{\mathrm{C}} 129.24 \mathrm{ppm}\right) ; \mathrm{H}-3\left(\delta_{\mathrm{H}} 4.83 \mathrm{ppm}, 1 \mathrm{H}\right.$, $\mathrm{d}, J=11.95 \mathrm{~Hz})$ to $\mathrm{C}-2 \quad\left(\delta_{\mathrm{C}} 82.72 \mathrm{ppm}\right), \mathrm{C}-4 \quad\left(\delta_{\mathrm{C}}\right.$ $197.91 \mathrm{ppm}), \mathrm{C}-1^{\prime}\left(\delta_{\mathrm{C}} 130.49 \mathrm{ppm}\right), \mathrm{C}-5^{\prime \prime}\left(\delta_{\mathrm{C}} 157.37 \mathrm{ppm}\right)$, C-6" ${ }^{\prime \prime}\left(\delta_{\mathrm{C}} 102.02 \mathrm{ppm}\right), \mathrm{C}-7^{\prime \prime}\left(\delta_{\mathrm{C}} 163.31 \mathrm{ppm}\right)$. The olefinic $\mathrm{H}-3^{\prime \prime}$ proton $\left(\delta_{\mathrm{H}} 6.39 \mathrm{ppm}, 1 \mathrm{H}, \mathrm{s}\right)$ correlated to C-2" $\left(\delta_{\mathrm{C}}\right.$ $165.73 \mathrm{ppm}), \quad \mathrm{C}-4^{\prime \prime} \quad\left(\delta_{\mathrm{C}} 183.83 \mathrm{ppm}\right), \quad \mathrm{C}-10^{\prime \prime} \quad\left(\delta_{\mathrm{C}}\right.$ 
$104.95 \mathrm{ppm}), \mathrm{C}-1^{\prime \prime \prime}\left(\delta_{\mathrm{C}} 123.34 \mathrm{ppm}\right)$. The correspondence of ten aromatic protons is displayed in $\mathrm{H}-6\left(\delta_{\mathrm{H}} 5.96 \mathrm{ppm}\right.$, $1 \mathrm{H}, \mathrm{d}, J=2.15 \mathrm{~Hz})$ to $\mathrm{C}-5\left(\delta_{\mathrm{C}} 164.81 \mathrm{ppm}\right), \mathrm{C}-8\left(\delta_{\mathrm{C}}\right.$ $96.42 \mathrm{ppm}), \mathrm{C}-10\left(\delta_{\mathrm{C}} 103.19 \mathrm{ppm}\right) ; \mathrm{H}-8\left(\delta_{\mathrm{H}} 5.98 \mathrm{ppm}, 1 \mathrm{H}\right.$, $\mathrm{d}, J=2.15 \mathrm{~Hz})$ to $\mathrm{C}-6\left(\delta_{\mathrm{C}} 97.43 \mathrm{ppm}\right), \mathrm{C}-7\left(\delta_{\mathrm{C}} 165.73 \mathrm{ppm}\right)$, C-9 $\left(\delta_{\mathrm{C}} 168.19 \mathrm{ppm}\right), \mathrm{C}-10\left(\delta_{\mathrm{C}} 103.19 \mathrm{ppm}\right) ; \mathrm{H}-2^{\prime}\left(\delta_{\mathrm{H}}\right.$ $7.07 \mathrm{ppm}, 1 \mathrm{H}, \mathrm{d}, J=8.30 \mathrm{~Hz})$ to $\mathrm{C}-2\left(\delta_{\mathrm{C}} 82.72 \mathrm{ppm}\right), \mathrm{C}-4^{\prime}$ $\left(\delta_{\mathrm{C}} 158.81 \mathrm{ppm}\right), \mathrm{C}-6^{\prime}\left(\delta_{\mathrm{C}} 129.24 \mathrm{ppm}\right) ; \mathrm{H}-3^{\prime}\left(\delta_{\mathrm{H}} 6.64 \mathrm{ppm}\right.$, $1 \mathrm{H}, \mathrm{d}, J=8.05 \mathrm{~Hz})$ to $\mathrm{C}-2^{\prime}\left(\delta_{\mathrm{C}} 129.24 \mathrm{ppm}\right) ; \mathrm{H}-5^{\prime}\left(\delta_{\mathrm{H}}\right.$ $6.43 \mathrm{ppm}, 1 \mathrm{H}, \mathrm{d}, J=8.10 \mathrm{~Hz})$ to $\mathrm{C}-3^{\prime}\left(\delta_{\mathrm{C}} 115.61 \mathrm{ppm}\right) ; \mathrm{H}-6^{\prime}$ $\left(\delta_{\mathrm{H}} 7.10 \mathrm{ppm}, 1 \mathrm{H}, \mathrm{d}, J=8.25 \mathrm{~Hz}\right)$ to $\mathrm{C}-2\left(\delta_{\mathrm{C}} 82.72 \mathrm{ppm}\right)$, $\mathrm{C}-2^{\prime}\left(\delta_{\mathrm{C}} 129.24 \mathrm{ppm}\right), \mathrm{C}-4^{\prime}\left(\delta_{\mathrm{C}} 158.81 \mathrm{ppm}\right) ; \mathrm{H}-8^{\prime \prime}\left(\delta_{\mathrm{H}}\right.$ $6.25 \mathrm{ppm}, 1 \mathrm{H}, \mathrm{s})$ to $\mathrm{C}-6^{\prime \prime}\left(\delta_{\mathrm{C}} 102.02 \mathrm{ppm}\right), \mathrm{C}-7^{\prime \prime}\left(\delta_{\mathrm{C}}\right.$ $163.31 \mathrm{ppm}), \quad \mathrm{C}-9^{\prime \prime} \quad\left(\delta_{\mathrm{C}} \quad 162.53 \mathrm{ppm}\right), \quad \mathrm{C}-10^{\prime \prime} \quad\left(\delta_{\mathrm{C}}\right.$ $104.95 \mathrm{ppm}) ; \mathrm{H}-2^{\prime \prime \prime}\left(\delta_{\mathrm{H}} 7.33 \mathrm{ppm}, 1 \mathrm{H}, \mathrm{m}\right)$ to $\mathrm{C}-2^{\prime \prime}\left(\delta_{\mathrm{C}}\right.$ $165.73 \mathrm{ppm}), \quad \mathrm{C}-3^{\prime \prime \prime} \quad\left(\delta_{\mathrm{C}} \quad 146.79 \mathrm{ppm}\right), \quad \mathrm{C}-4^{\prime \prime \prime} \quad\left(\delta_{\mathrm{C}}\right.$ $150.94 \mathrm{ppm}), \mathrm{C}-6^{\prime \prime \prime}\left(\delta_{\mathrm{C}} 120.55 \mathrm{ppm}\right) ; \mathrm{H}-5^{\prime \prime \prime}\left(\delta_{\mathrm{H}} 6.91 \mathrm{ppm}\right.$, $1 \mathrm{H}, \mathrm{d}, J=8.35 \mathrm{~Hz})$ to $\mathrm{C}-1^{\prime \prime \prime}\left(\delta_{\mathrm{C}} 123.34 \mathrm{ppm}\right), \mathrm{C}-3^{\prime \prime \prime}\left(\delta_{\mathrm{C}}\right.$ $146.79 \mathrm{ppm}), \mathrm{C}-4^{\prime \prime \prime}\left(\delta_{\mathrm{C}} 150.94 \mathrm{ppm}\right) ;$ and $\mathrm{H}-6^{\prime \prime \prime}\left(\delta_{\mathrm{H}}\right.$ $7.29 \mathrm{ppm}, 1 \mathrm{H}, \mathrm{d}, J=8.40 \mathrm{~Hz})$ to $\mathrm{C}-2^{\prime \prime}\left(\delta_{\mathrm{C}} 165.73 \mathrm{ppm}\right)$, $\mathrm{C}-2^{\prime \prime \prime}\left(\delta_{\mathrm{C}} 114.17 \mathrm{ppm}\right), \mathrm{C}-4^{\prime \prime \prime}\left(\delta_{\mathrm{C}} 150.94 \mathrm{ppm}\right)$. The correlations between neighboring protons were indicated in the COSY spectrum data of $\mathrm{H}-2$ with $\mathrm{H}-3$; $\mathrm{H}-2^{\prime}$ with $\mathrm{H}-3^{\prime}$; $\mathrm{H}-5^{\prime}$ with $\mathrm{H}-6^{\prime}$; and $5^{\prime \prime \prime}$ with $6^{\prime \prime \prime}$. The two-dimensional correlation of the HMBC and the COSY cross-peaks is displayed in Figure 1.

Molecular assembly based on interpretation of 1D- and 2D-NMR data specified a flavanone skeletal pattern with naringenin feature [31-34] and a flavone skeletal pattern with luteolin feature $[35,36]$ constructing the compound $\mathbf{1}$ which is named macrophylloflavone. The molecular structure of 1 was also supported by its features based on the presence of chromophore in the UV spectra and the massto-charge ratio of FTIR. The NMR data for compound $\mathbf{1}$ were then confirmed by the NMR data from known compounds, i.e., morelloflavone [37-42], its glucoside derivative [30], and volkensiflavone [43], which have similar characteristics as shown in Tables 1 and 2. Analyses based on comparison with the spectroscopic data between compound 1 and a number of known related flavonoid dimers exhibited structural resemblance excluding for C-C linkage between flavanone-flavone moieties as shown in Figure 2.

The existence of the chemical shifts at $\delta_{\mathrm{H}}(\mathrm{ppm}) 5.75(1 \mathrm{H}$, d, $J=11.90 \mathrm{~Hz}, \mathrm{H}-2), 4.83(1 \mathrm{H}, \mathrm{d}, J=11.95 \mathrm{~Hz}, \mathrm{H}-3), 5.96$ $(1 \mathrm{H}, \mathrm{d}, J=2.15 \mathrm{~Hz}, \mathrm{H}-6), 5.98(1 \mathrm{H}, \mathrm{d}, J=2.15 \mathrm{~Hz}, \mathrm{H}-8), 7.07$ $\left(1 \mathrm{H}, \mathrm{d}, J=8.30 \mathrm{~Hz}, \mathrm{H}-2^{\prime}\right), 6.64\left(1 \mathrm{H}, \mathrm{d}, J=8.05 \mathrm{~Hz}, \mathrm{H}-3^{\prime}\right), 6.43$ $\left(1 \mathrm{H}, \mathrm{d}, J=8.10 \mathrm{~Hz}, \mathrm{H}-5^{\prime}\right)$, and $7.10\left(1 \mathrm{H}, \mathrm{d}, J=8.25 \mathrm{~Hz}, \mathrm{H}-6^{\prime}\right)$ exposed the same pattern as the naringenin compound [31-34]. The appearance of the signals at $\delta_{\mathrm{H}}(\mathrm{ppm}) 5.75(1 \mathrm{H}$, $\mathrm{d}, J=11.90 \mathrm{~Hz}, \mathrm{H}-2)$ and $4.83(1 \mathrm{H}, \mathrm{d}, J=11.95 \mathrm{~Hz}, \mathrm{H}-3)$ confirmed the trans-vicinal proton-proton relationship at the aliphatic carbon of the flavanone unit. The difference in chemical shift values between $\mathrm{H}-2$ and $\mathrm{H}-3$ was due to the electronegative influence of the oxygen atom in the $\mathrm{sp}^{3}$ hybridization carbon chain. $\mathrm{H}-2$ was deshielded by adjacent oxygen atom and has a higher chemical shift than $\mathrm{H}-3$ which was deshielded to a reduced magnitude of the carbonyl carbon [45]. In the meantime, the signals appeared at $\delta_{\mathrm{H}}$ (ppm) $6.39\left(1 \mathrm{H}, \mathrm{s}, \mathrm{H}-3^{\prime \prime}\right), 6.25\left(1 \mathrm{H}, \mathrm{s}, \mathrm{H}-8^{\prime \prime}\right), 7.33(1 \mathrm{H}, \mathrm{m}$,
$\left.\mathrm{H}-2^{\prime \prime \prime}\right), 6.91\left(1 \mathrm{H}, \mathrm{d}, J=8.35 \mathrm{~Hz}, \mathrm{H}-5^{\prime \prime \prime}\right)$, and $7.29(1 \mathrm{H}, \mathrm{d}$, $\left.J=8.40 \mathrm{~Hz}, \mathrm{H}-6^{\prime \prime \prime}\right)$ confirmed the same pattern as the luteolin compound; also, the signal at $\delta_{\mathrm{H}}(\mathrm{ppm}) 6.39(1 \mathrm{H}, \mathrm{s}$, $\left.\mathrm{H}-3^{\prime \prime}\right)$ established the presence of a vinylic proton at flavone unit $[35,36]$. In addition, such data was very much in accordance with the published data on the related biflavonoid compounds [30, 37-43].

The signals at $\delta_{\mathrm{C}-4^{\prime \prime}} 183.83 \mathrm{ppm}$ and $\delta_{\mathrm{C}-4} 197.91 \mathrm{ppm}$ were a unique attribute for carbonyl carbon at a dimeric flavonoid compound. Moreover, the signals at $\delta_{\mathrm{C}-2} 82.72 \mathrm{ppm}, \delta_{\mathrm{C}-3}$ $50.84 \mathrm{ppm}, \quad \delta_{\mathrm{C}-6} \quad 97.43 \mathrm{ppm}, \quad \delta_{\mathrm{C}-8} \quad 96.42 \mathrm{ppm}, \quad \delta_{\mathrm{C}-3}{ }^{\prime \prime}$ $103.37 \mathrm{ppm}, \delta_{\mathrm{C}-6^{\prime \prime}} 102.02 \mathrm{ppm}$, and $\delta_{\mathrm{C}-8^{\prime \prime}} 99.83 \mathrm{ppm}$ were a unique feature of the flavanone[3-6"] flavone skeleton pattern. It was clearly confirmed that the $\delta_{\mathrm{C}-6^{\prime \prime}}$ appeared in the downfield region and the $\delta_{\mathrm{C}-8^{\prime \prime}}$ existed in the upfield region. Referring to the $\delta_{\mathrm{C}-6^{\prime \prime}}$ and $\delta_{\mathrm{C}-8^{\prime \prime}}$ values of compounds 2,3 , and 4 , the $\delta_{\mathrm{C}-6^{\prime \prime}}$ value always appeared in the upfield area compared to the $\delta_{\mathrm{C}-8^{\prime \prime}}$ value which exists in the downfield area where the linkage occurs in the flavanone[3$8^{\prime \prime}$ ] flavone skeleton pattern [30, 39-42, 44]. Linkage performance between C-3 in flavanone moiety and C- 6 " in flavone moiety could also be observed through the HMBC relationship of compound $\mathbf{1}$ which was compared with the $\mathrm{HMBC}$ of compound 3 as shown in Figure 2. The overall assignment based on spectroscopic data of compound $\mathbf{1}$, by comparing data to the model compounds, demonstrated that macrophylloflavone (1) is a new biflavonoid compound with linkage flavanone[3-6"] flavone system.

3.2. Antibacterial Activity. The classification of antimicrobial strength such as weak, moderate, and strong is indicated by the inhibition zones of $<12,12-20$, and $>20 \mathrm{~mm}$, respectively [46]. Based on the results, the biflavonoid compound $\mathbf{1}$ was found to have strong antimicrobial activity against both the E. coli and the $S$. aureus bacteria. The inhibition zones in various concentrations were found to be around $16.65 \pm 0.43$ to $20.29 \pm 0.28 \mathrm{~mm}$ (mean $\pm \mathrm{SD}$ ) for $E$. $\operatorname{coli}(30 \mu \mathrm{g} / \mathrm{mL}, 60 \mu \mathrm{g} / \mathrm{mL}$, and $120 \mu \mathrm{g} / \mathrm{mL})$. Meanwhile, for $S$. aureus, the inhibition zone was around $15.54 \pm 0.39$ to $23.16 \pm 0.32 \mathrm{~mm}$ (mean $\pm \mathrm{SD})$. The antibacterial properties of flavonoids were based on their ability to inhibit nucleic acid synthesis, cytoplasmic membrane function, energy metabolism, and porins in cell membranes [47].

3.3. Antioxidant Activity. The antioxidant performance of the compound $\mathbf{1}$ against $\mathrm{DPPH}$ free radicals gave the $\mathrm{IC}_{50}$ values of $3.69 \pm 0.29 \mu \mathrm{g} / \mathrm{mL}$ (mean $\pm \mathrm{SD}$ ). The strength of an antioxidant's activity is based on the $\mathrm{IC}_{50}$ value criteria; i.e., the $\mathrm{IC}_{50}$ value $<10 \mu \mathrm{g} / \mathrm{mL}$ indicates very strong activity, the value $10-50 \mu \mathrm{g} / \mathrm{mL}$ suggests strong activity, the value $50-100 \mu \mathrm{g} / \mathrm{mL}$ implies moderate activity, the value $100-250 \mu \mathrm{g} / \mathrm{mL}$ reveals weak activity, and the value $>250 \mu \mathrm{g} /$ $\mathrm{mL}$ signifies no activity [48]. In this research, the $\mathrm{IC}_{50}$ value of compound 1 was found to be $<10 \mu \mathrm{g} / \mathrm{mL}$ indicating a very strong antioxidant activity. Almost all flavonoid compounds are antioxidants. It is ascribed to their possession of hydroxyl groups in the flavonoids [49]. The compound $\mathbf{1}$ acted as an antioxidant agent donating its hydrogen atoms from the 


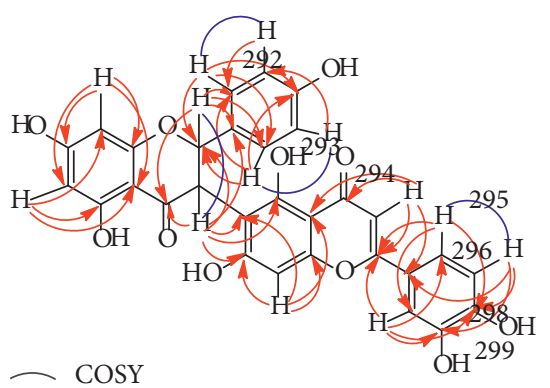

(a)

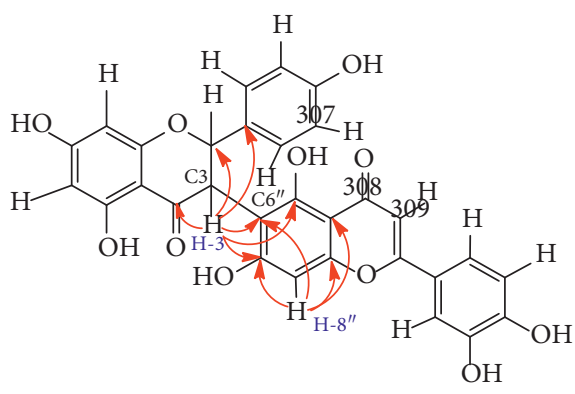

(c)

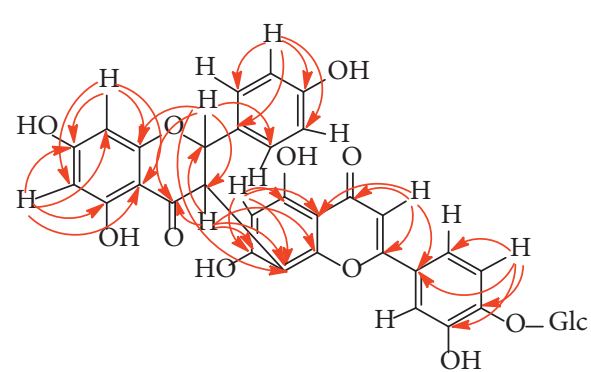

(b)

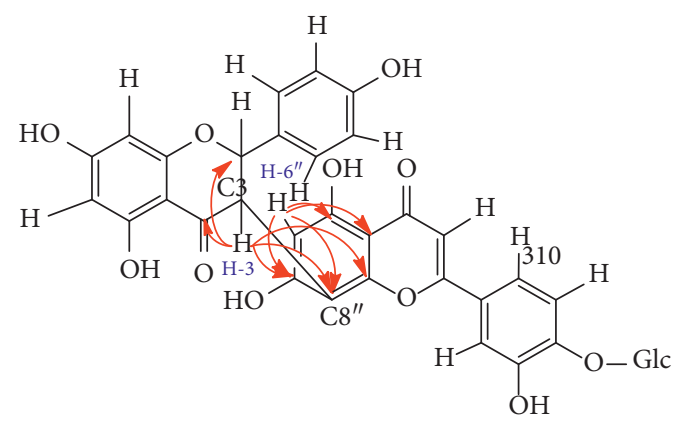

(d)

Figure 1: Comparison of HMBC correlation between $\mathbf{1}$ and $\mathbf{3}$ compounds. (a) Macrophylloflavone (1). (b) HMBC of morelloflavone- $\mathbf{4}^{\prime \prime \prime}-\mathrm{O}-$ $\beta$-D-glucoside (3) [30]. (c) HMBC of 3-flavanone-6"-flavone. (d) HMBC of 3-flavanone-8"-flavone [30].

substituent content of the hydroxyl groups towards DPPH free radical, allowing the reduction of the DPPH radical. The reduction of $\mathrm{DPPH}$ radicals can be observed through the color change, from purple (DPPH) to yellow (1,1-diphenyl2-picrylhydrazine) [50].

3.4. Anti-Type 2 Diabetes Mellitus Activity. The compound $\mathbf{1}$ has the ability to reduce the blood glucose levels in rats with diabetes (Figure 3 ). Several studies have reported that flavonoids contribute to the prevention of diabetes mellitus by regenerating the formation of $\beta$-cells pancreas which acts to produce insulin. The formation allows the decrease of glucose by converting it into energy, thus maintaining the blood glucose levels under a normal condition [51].

The results of the group treatment in decreasing the blood glucose levels are presented in Table 3 and Figure 3. The data were analyzed with two-way ANOVA to interpret the significance of the interaction effect at $F(8,40)=146.2$, $p<0.0001$. The main effect between treatment (doses of compound 1) and control (negative and positive controls) referred as $F(2,40)=2985, p<0.0001$, produces a significantly different value in blood glucose levels at the posttreatment (mean $\pm \mathrm{SD}$ ), namely, negative control $(412.20 \pm 7.76)$, positive control $(98.00 \pm 1.67)$, dose $6 \mu \mathrm{g} / \mathrm{kg}$ body weight $(171.00 \pm 3.81)$, dose $7 \mu \mathrm{g} / \mathrm{kg}$ body weight $(138.00 \pm 1.87)$, and a dose of $8 \mu \mathrm{g} / \mathrm{kg}$ body weight $(108.40 \pm 3.21)$. According to the American Diabetes Association, blood glucose levels $>180 \mathrm{mg} / \mathrm{dL}$ indicate hyperglycemia, while the levels $<100 \mathrm{mg} / \mathrm{dL}$ indicate hypoglycemia [52]. Therefore, it could be assumed that blood glucose levels given by the treatment group were found to be within the normal range. The blood glucose levels in the positive control group, however, indicate the risk of hypoglycemia. The blood glucose levels produced the main effect at $\mathrm{F}$ ratio of $F(4,20)=239, p<0.0001$ generating the significant force. The analysis of Tukey's post hoc test showed that the positive control has a significant different effect of compound 1 on the dose of $6 \mu \mathrm{g} / \mathrm{kg}$ body weight $(p<0.0001), 7 \mu \mathrm{g} / \mathrm{kg}$ body weight $(p=0.0049)$, and $8 \mu \mathrm{g} / \mathrm{kg}$ body weight $(p=0.0055)$. This means that all variations of compound $\mathbf{1}$ dosage have antidiabetic activity better than the positive control, but a very significant different result in reducing blood glucose in diabetic rats was shown by compound 1 at a dose of $6 \mu \mathrm{g} / \mathrm{kg}$ body weight. In other words, there were variations in the high and low doses of compound $\mathbf{1}$ have no effect in decreasing the blood glucose of diabetic rats.

Decreasing of blood glucose levels in diabetic rats was caused by the activity of flavonoid dimers in compound $\mathbf{1}$, i.e., naringenin and luteolin. Flavonoid compounds have double bonds, carbonyl groups, and hydroxy groups which are very important in the antidiabetic activity [53]. Naringenin and luteolin, in particular, have been reported to have the ability to overcome the hyperglycemia by inhibiting intestinal $\alpha$-glucosidase activity, reducing oxidative stress, increasing antioxidant enzymes, and stimulating insulin secretion $[54,55]$. The results of the decrease in blood sugar levels obtained after administration of compound $\mathbf{1}$ conclusively proved that the macrophylloflavone (1) has antitype 2 diabetes property. 


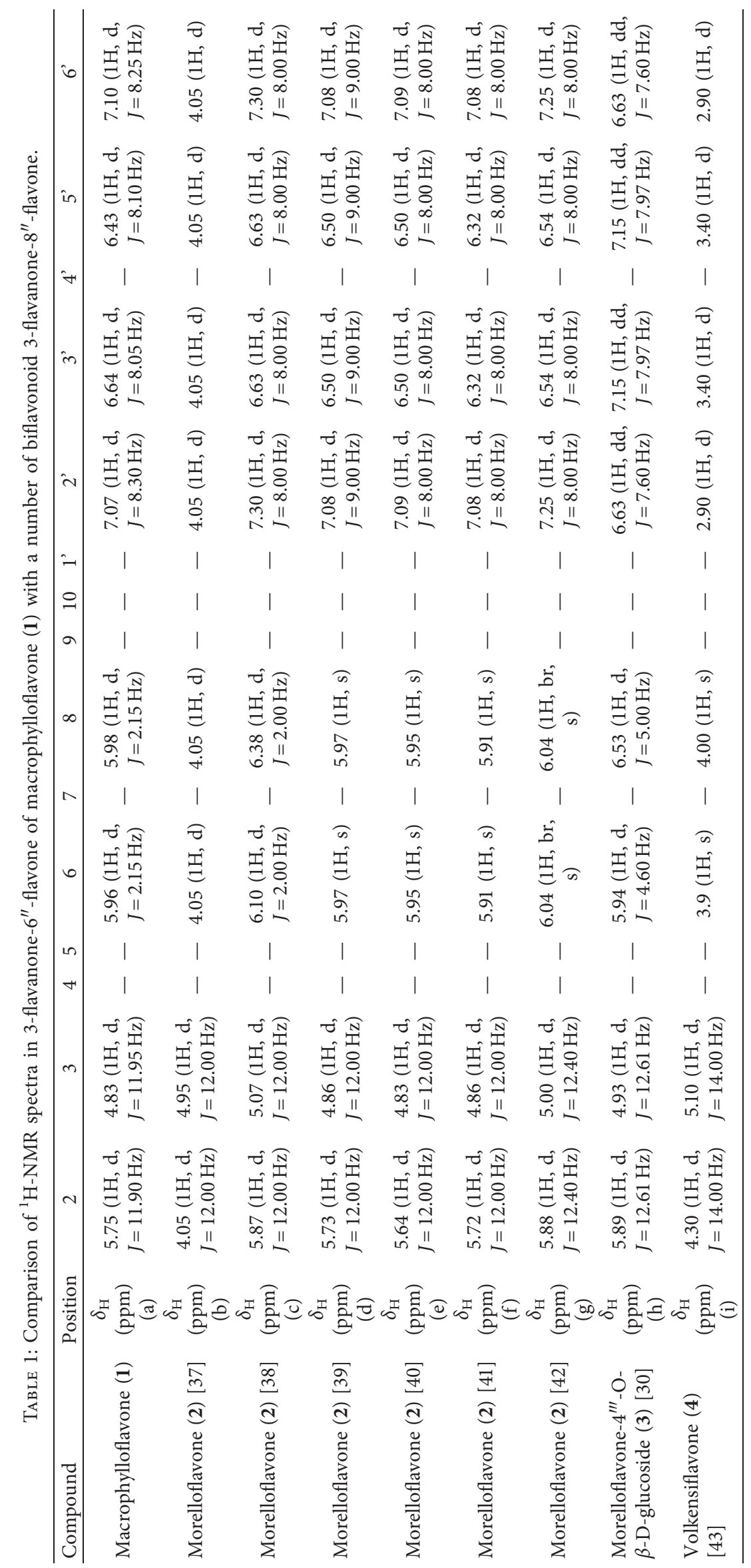




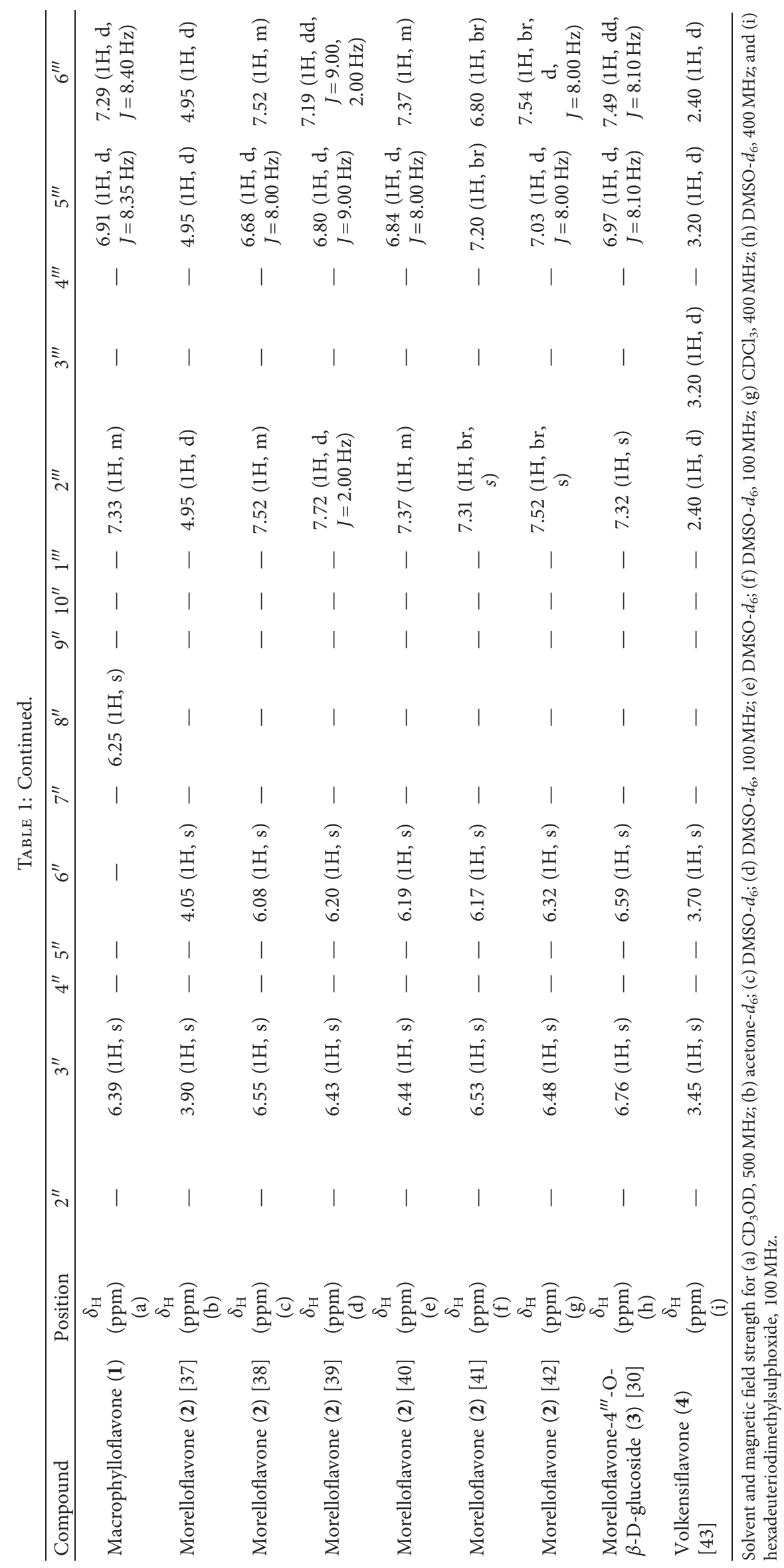




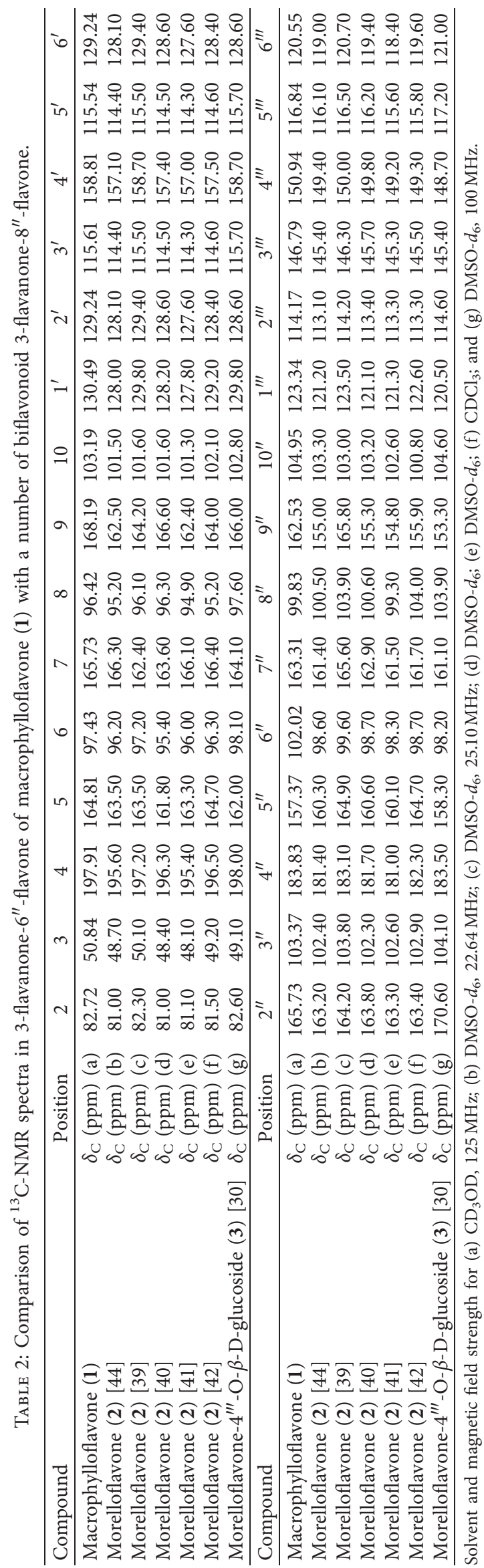



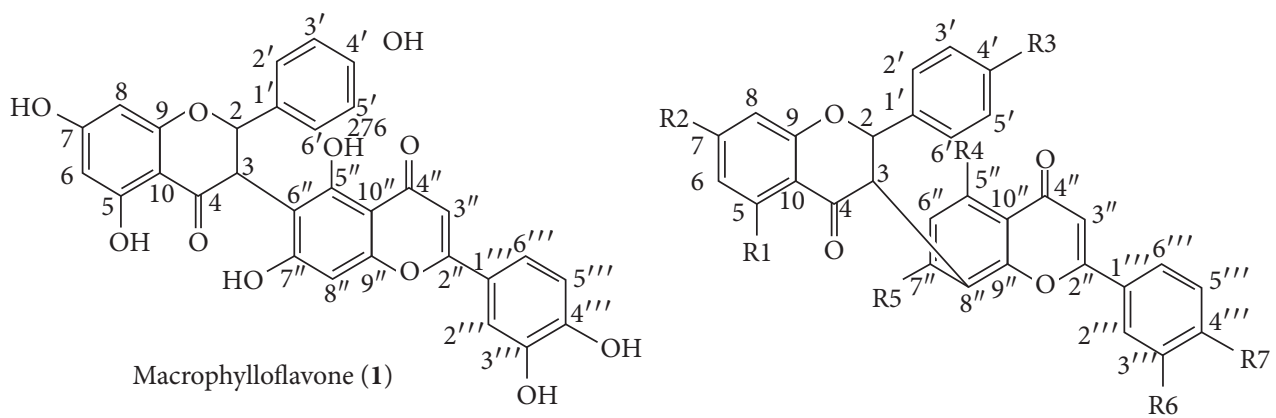

Macrophylloflavone (2), $\mathrm{R} 1=\mathrm{R} 2=\mathrm{R} 3=\mathrm{R} 4=\mathrm{R} 5=\mathrm{R} 6=\mathrm{R} 7=\mathrm{OH}$

Macrophylloflavone $-4^{\prime \prime \prime}-\mathrm{Glc}(3), \mathrm{R} 1=\mathrm{R} 2=\mathrm{R} 3=\mathrm{R} 4=\mathrm{R} 5=\mathrm{R} 6=\mathrm{OH}, \mathrm{R} 7=\mathrm{Glc}$

Macrophylloflavone (4), R1 = R2 = R3 = R4 = R5 = R7 = OH, R6 = H

Figure 2: Macrophylloflavone (1); morelloflavone (2) [37-42]; morelloflavone-4'"'-O- $\beta$-D- glucoside (3) [30]; and volkensiflavone (4) [43].

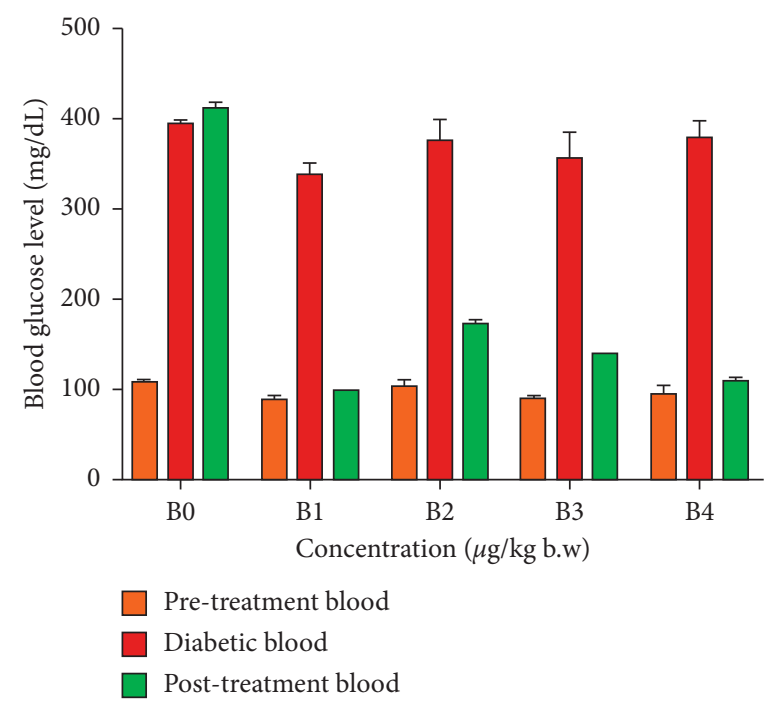

FIGURE 3: Histogram chart of the relationship of each group's treatment to changes in blood glucose levels.

The histopathological data of kidney tubular cells, pancreatic $\beta$-cells, and liver hepatocytes cell required the normal rat cells (given code $\mathrm{A}$ ), as a benchmark in the observations. The data in Table 4 have shown changes in the number of kidney tubular cells, pancreatic $\beta$-cells, and liver hepatocytes cells. These were ascribed to the presence of necrosis in cells by glucose monohydrate (alloxan). Alloxan can cause significant damage to these cells by triggering the formation of free radicals that lead to diabetes in rats [56].

The administration of the compound $\mathbf{1}$ (on doses of $\mathrm{B} 2$, $\mathrm{B} 3$, and B4) reduced the necrosis in kidney tubular cells (Table 4). It was evident that the compound 1 could repair the tubular cell damage in the kidney. The number of necrotic cells in the kidney tubules in the treatment group with $8 \mu \mathrm{g} / \mathrm{kg}$ body weight dose (B4) revealed the similarities with the normal rat kidney tubules (A) $(p<0.05)$. The kidneys contribute to glucose homeostasis through the processes of gluconeogenesis, glucose filtration, glucose reabsorption, and glucose consumption [57]. Kidney gluconeogenesis is more sensitive to insulin. The condition of diabetes results in an increase in kidney glucose production that is not proportional to the amount of insulin, hence the consequent reduction in glucose absorption in the proximal tubule by the insulin-independent process [58]. Excessive glucose and oxidative stress in the kidneys cause damage to tubular cells. The antioxidant properties of the compound 1 have produced a positive effect in preventing damage to kidney tubular cells so that the appearance of tubular cells is closer to the appearance of tubules under normal conditions (Figure 4).

An increase in the number of pancreatic $\beta$-cells has occurred in the administration of the compound $\mathbf{1}$ at various doses (B2, B3, and B4) (Table 4). Administration of the compound 1 with a dose of $8 \mu \mathrm{g} / \mathrm{kg}$ body weight (B4) has to afford no difference in the number of normal pancreatic $\beta$-cells (A) $(p<0.05)$. Application of the compound 1 was observed to increase the formation of $\beta$-cells in the pancreas (Figure 5). This was possible due to the compound $\mathbf{1}$ ability to neutralize free radicals that inhibit the formation of $\beta$-cells in the pancreas. Flavonoid compounds in the case of 
TABLE 3: The effect of compound 1 on blood glucose levels of diabetic rats.

\begin{tabular}{|c|c|c|c|c|}
\hline \multirow{2}{*}{ No. } & \multirow{2}{*}{ Treatment } & \multicolumn{3}{|c|}{ Blood glucose levels $($ mean $\pm \mathrm{SD}, \mathrm{mg} / \mathrm{dL})$} \\
\hline & & Pretreatment blood & Diabetic blood & Posttreatment blood \\
\hline \multirow{5}{*}{1} & B0 & $105.00 \pm 3.94$ & $396.00 \pm 3.67$ & $412.20 \pm 7.76$ \\
\hline & B1 & $88.20 \pm 4.17$ & $339.20 \pm 12.49$ & $98.00 \pm 1.67$ \\
\hline & $\mathrm{B} 2$ & $103.40 \pm 6.80$ & $377.00 \pm 25.33$ & $171.00 \pm 3.81$ \\
\hline & B3 & $87.00 \pm 4.42$ & $357.40 \pm 28.87$ & $138.00 \pm 1.87$ \\
\hline & $\mathrm{B} 4$ & $93.80 \pm 11.12$ & $379.40 \pm 21.33$ & $108.40 \pm 3.21$ \\
\hline \multirow{4}{*}{2} & ANOVA table & F (DFn, DFd) & $p$ value & \\
\hline & Interaction & $F(8,40)=146.2$ & $<0.0001$ & \\
\hline & Dose (biflavonoid and control) & $F(2,40)=2985$ & $<0.0001$ & \\
\hline & Blood glucose level & $F(4,20)=239$ & $<0.0001$ & \\
\hline \multirow{5}{*}{3} & Tukey's post hoc test & $p$ value & Significant? & \\
\hline & $\mathrm{B} 0$ versus $\mathrm{B} 1$ & $<0.0001$ & Yes & \\
\hline & $\mathrm{B} 1$ versus $\mathrm{B} 2$ & $<0.0001$ & Yes & \\
\hline & $B 1$ versus $B 3$ & 0.0049 & Yes & \\
\hline & $\mathrm{B} 1$ versus $\mathrm{B} 4$ & 0.0055 & Yes & \\
\hline
\end{tabular}

Different letters indicate significant differences between the groups $(p<0.05)$. Tukey's post hoc test following the two-way ANOVA. B0: the negative control, B1: the positive control, B2: the compound 1 given at a dose of $6 \mu \mathrm{g} / \mathrm{kg}$ body weight, B3: the compound 1 given at a dose of $7 \mu \mathrm{g} / \mathrm{kg}$ body weight, B4: the compound 1 given at a dose of $8 \mu \mathrm{g} / \mathrm{kg}$ body weight.

TABLE 4: A total number of cells on histology of kidney, pancreas, and liver of rats in various groups.

\begin{tabular}{|c|c|c|c|c|c|}
\hline \multirow[b]{2}{*}{ Treatment } & \multicolumn{2}{|c|}{ Histology of rat kidney } & \multirow{2}{*}{$\begin{array}{c}\text { Histology of rat } \\
\text { pancreas } \\
\text { Beta cells of pancreatic } \\
\text { (cells } \pm \text { SD) }\end{array}$} & \multicolumn{2}{|c|}{ Histology of rat liver } \\
\hline & $\begin{array}{c}\text { Normal cells of } \\
\text { tubules (cells } \pm S D)\end{array}$ & $\begin{array}{l}\text { Necrosis cells of } \\
\text { tubules (cells } \pm \text { SD) }\end{array}$ & & $\begin{array}{c}\text { Normal cells of } \\
\text { hepatocyte (cells } \pm \text { SD) }\end{array}$ & $\begin{array}{c}\text { Necrosis cells of } \\
\text { hepatocyte }(\text { cells } \pm S D)\end{array}$ \\
\hline A & $382 \pm 8.72^{\mathrm{a}}$ & $103 \pm 12.49^{\mathrm{e}}$ & $286 \pm 13.00^{\mathrm{a}}$ & $298 \pm 8.19^{\mathrm{a}}$ & $75 \pm 9.17^{\mathrm{d}}$ \\
\hline B0 & $299 \pm 13.53^{c}$ & $162 \pm 4.36^{\mathrm{a}}$ & $184 \pm 8.00^{\mathrm{d}}$ & $262 \pm 13.08^{\mathrm{c}}$ & $113 \pm 6.56^{\mathrm{a}}$ \\
\hline B1 & $328 \pm 17.35^{\mathrm{b}}$ & $136 \pm 7.94^{\mathrm{bc}}$ & $252 \pm 7.81^{\mathrm{c}}$ & $281 \pm 9.54^{\mathrm{ab}}$ & $91 \pm 4.58^{\mathrm{bc}}$ \\
\hline B2 & $285 \pm 15.09^{c}$ & $154 \pm 14.00^{\mathrm{ab}}$ & $241 \pm 7.21^{\mathrm{c}}$ & $276 \pm 10.00^{\mathrm{bc}}$ & $102 \pm 12.17^{\mathrm{ab}}$ \\
\hline B3 & $343 \pm 5.29^{b}$ & $127 \pm 6.24^{\mathrm{cd}}$ & $269 \pm 9.64^{b}$ & $284 \pm 7.81^{\mathrm{ab}}$ & $86 \pm 6.08^{\mathrm{cd}}$ \\
\hline B4 & $374 \pm 10.44^{\mathrm{a}}$ & $112 \pm 14.93^{\mathrm{de}}$ & $280 \pm 7.00^{\mathrm{ab}}$ & $287 \pm 4.36^{\mathrm{ab}}$ & $78 \pm 8.54^{\mathrm{cd}}$ \\
\hline
\end{tabular}

A: the blank control, B0: the negative control, B1: the positive control, B2: the compound 1 given at a dose of $6 \mu \mathrm{g} / \mathrm{kg}$ body weight, B3: the compound 1 given at a dose of $7 \mu \mathrm{g} / \mathrm{kg}$ body weight, B4: the compound 1 given at a dose of $8 \mu \mathrm{g} / \mathrm{kg}$ body weight. Different letters showed significant differences between the groups $(p<0.05)$.

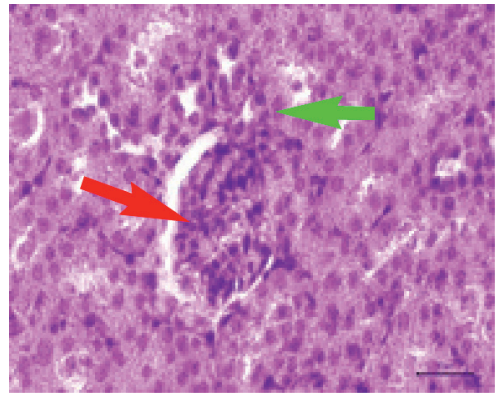

(a)

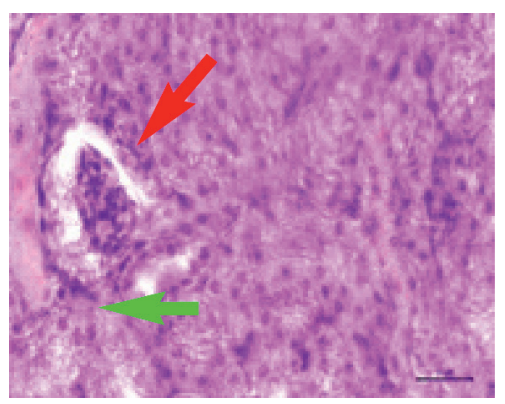

(d)

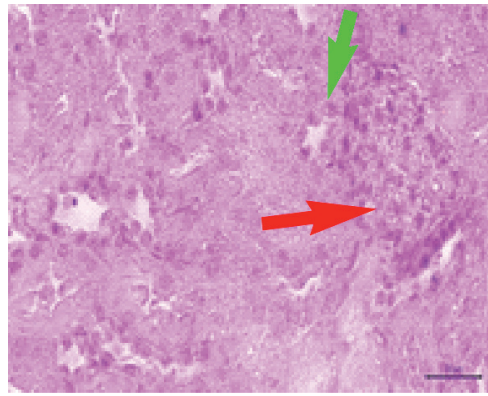

(b)

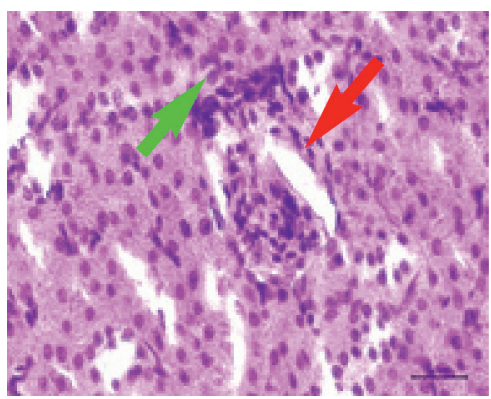

(e)

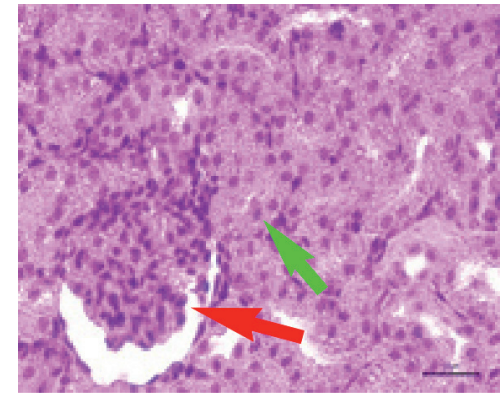

(c)

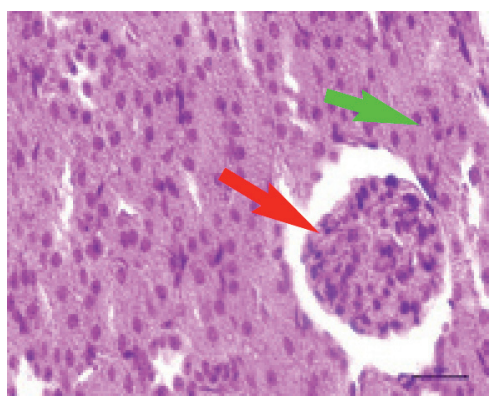

(f)

FIgURE 4: The kidney histology of rat at the blank control and various treatment groups. Red arrow: glomerulus; green arrow: proximal tubule. (a) A. (b) B0. (c) B1. (d) B2. (e) B3. (f) B4. 


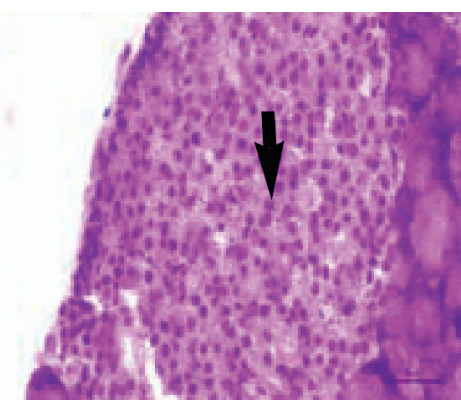

(a)

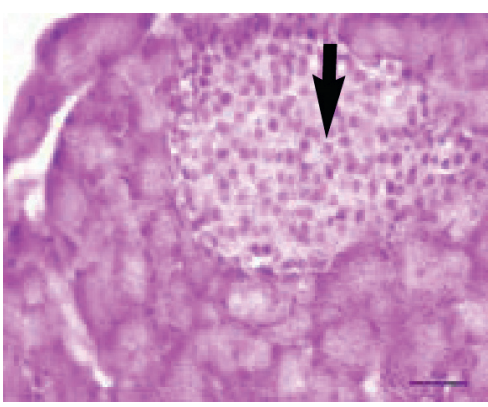

(d)

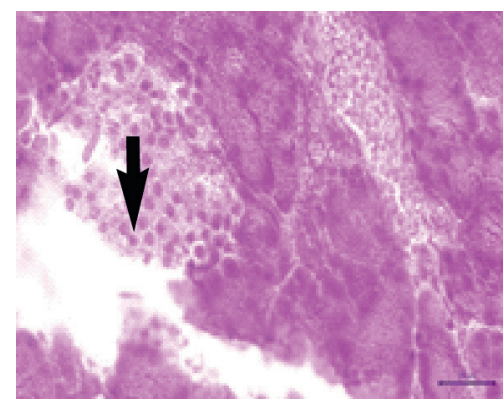

(b)

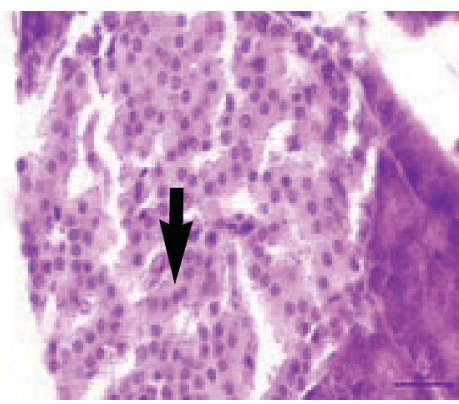

(e)

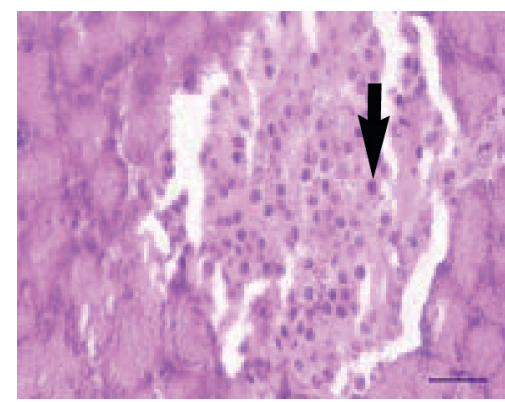

(c)

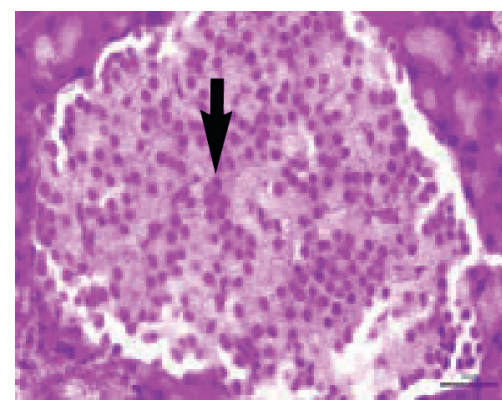

(f)

FiguRE 5: The pancreatic histology of rat at the blank control and various treatment groups. Black arrow: pancreatic beta cell. (a) A. (b) B0. (c) B1. (d) B2. (e) B3. (f) B4.

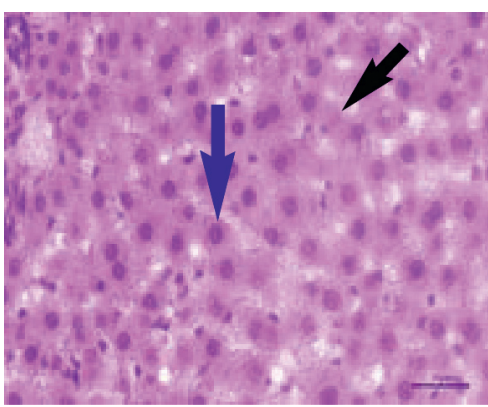

(a)

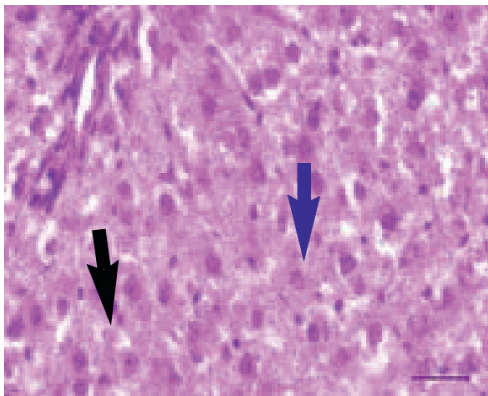

(d)

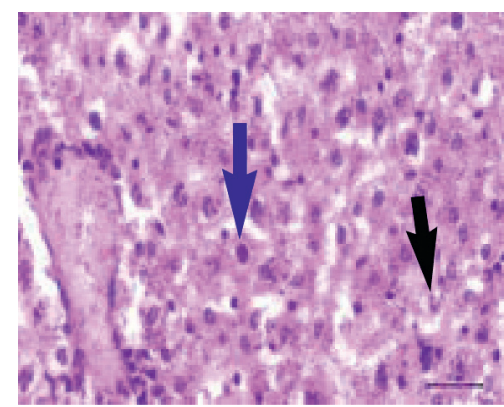

(b)

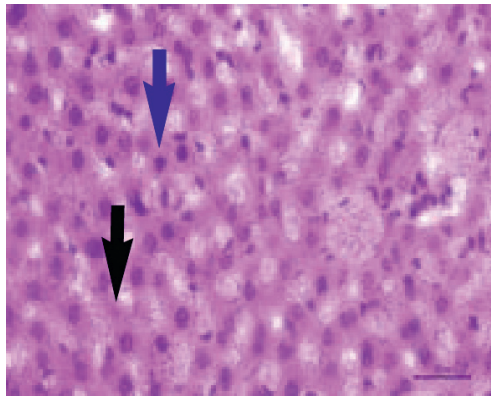

(e)

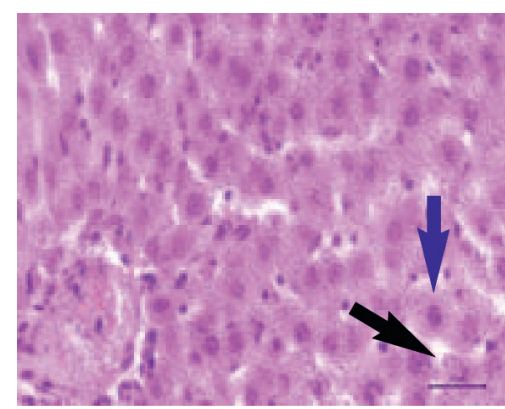

(c)

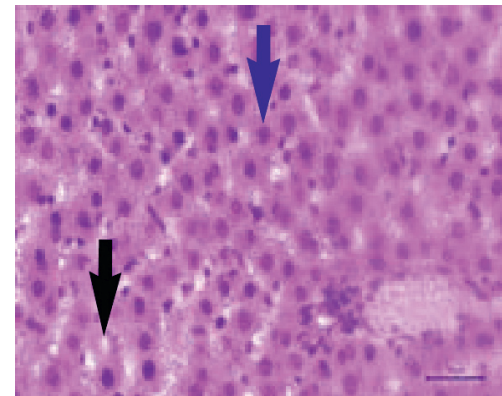

(f)

FIGURE 6: The liver histology of rat at the blank control and various treatment groups. Blue arrow: normal hepatocyte; black arrow: necrosis hepatocyte. (a) A. (b) B0. (c) B1. (d) B2. (e) B3. (f) B4.

diabetes were used for maintaining the function of $\beta$-cell pancreatic and increasing the reformation of $\beta$-cells in the pancreas [59].

The liver hepatocyte cell damage decreased after giving the compound 1 with various doses (B2, B3, and B4)
(Table 4). The compound $\mathbf{1}$ with dose of $7 \mu \mathrm{g} / \mathrm{kg}$ body weight (B3) and dose of $8 \mu \mathrm{g} / \mathrm{kg}$ body weight (B4) resulted in a number of liver hepatocyte necrosis cells same as the number of normal hepatocyte necrosis cells (A) $(p<0.05)$. The compound $\mathbf{1}$ was shown not to damage liver hepatocyte 
cells (not toxic) and regenerate liver hepatocyte cells in the normal range (Figure 6). Antioxidant agents based on liver pathology are administrated to repair or prevent various liver diseases which are commonly caused by oxidative stress disorders [60].

\section{Conclusions}

The macrophylloflavone (1) as new biflavonoid compound with linkage 3-flavanone- 6 "-flavone has been successfully isolated from the ethyl acetate fraction from the stem bark of G. macrophylla plant. The in vitro evaluation of $\mathbf{1}$ suggested strong antibacterial and also antioxidant activities. More importantly, the in vivo assay exhibited the ability of $\mathbf{1}$ to decrease blood glucose levels in the diabetic rats to the normal level.

\section{Data Availability}

The data generated to support the findings during this study are included within this article.

\section{Ethical Approval}

Ethical clearance approval for using animals in this study was granted by the Veterinary Ethics Committee of Faculty of Veterinary Medicine of Syiah Kuala University (Ref: 38/ KEPH/VIII/2019).

\section{Conflicts of Interest}

The authors declare that they have no conflicts of interest.

\section{Acknowledgments}

The authors would like to thank Kemenristekdikti for funding this research through the "PMDSU" scheme.

\section{References}

[1] G. Cenini, A. Lloret, and R. Cascella, "Oxidative stress in neurodegenerative diseases: from a mitochondrial point of view," Oxidative Medicine and Cellular Longevity, vol. 2019, Article ID 2105607, 18 pages, 2019.

[2] F. Collin, "Chemical basis of reactive oxygen species reactivity and involvement in neurodegenerative diseases," International Journal of Molecular Sciences, vol. 20, no. 2407, pp. 1-17, 2019.

[3] T. Rahman, I. Hosen, M. M. T. Islam, and H. U. Shekhar, "Oxidative stress and human health," Advances in Bioscience and Biotechnology, vol. 3, no. 3, pp. 997-1019, 2012.

[4] R. Sarangarajan, S. Meera, R. Rukkumani, P. Sankar, and G. Anuradha, "Antioxidants: friend or foe?" Asian Pacific Journal of Tropical Medicine, vol. 10, no. 12, pp. 1111-1116, 2017.

[5] A. Simamora, K. H. Timotius, and A. W. Santoso, "Antidiabetic, antibacterial and antioxidant activities of different extracts from brucea javanica (L.) merr seeds," Pharmacognosy Journal, vol. 11, no. 3, pp. 479-485, 2019.

[6] S. Rambhade, A. K. Chakraborty, U. K. Patil, and A. Rambhade, "Diabetes Mellitus- its complications, factors influencing complications and prevention- an overview,"
Journal of Chemical and Pharmaceutical Research, vol. 2, no. 6, pp. 7-25, 2010.

[7] N. Stankovic, T. Mihajilov-Krstev, B. Zlatkovic et al., "Antibacterial and antioxidant activity of traditional medicinal plants from the Balkan Peninsula," NJAS-Wageningen Journal of Life Sciences, vol. 78, pp. 21-28, 2016.

[8] J. M. Miranda, B. I. Vázquez, C. A. Fente, P. Calo-Mata, A. Cepeda, and C. M. Franco, "Comparison of antimicrobial resistance in Escherichia coli, Staphylococcus aureus, and Listeria monocytogenes strains isolated from organic and conventional poultry meat," Journal of Food Protection, vol. 71, no. 12, pp. 2537-2542, 2008.

[9] S. A. Mohammed, A. G. Yaqub, K. A. Sanda et al., "Review on diabetes, synthetic drugs and glycemic effects of medicinal plants," Journal of Medicinal Plants Research, vol. 7, no. 36, pp. 2628-2637, 2013.

[10] B. Paudel, H. D. Bhattarai, C. Kim et al., "Estimation of antioxidant, antimicrobial activity and brine shrimp toxicity of plants collected from Oymyakon region of the Republic of Sakha (Yakutia), Russia," Biological Research, vol. 47, no. 10, pp. 1-6, 2014.

[11] S. Hosseinzadeh, A. Jafarikukhdan, A. Hosseini, and R. Armand, "The application of medicinal plants in traditional and modern medicine: a review of Thymus vulgaris," International Journal of Clinical Medicine, vol. 6, no. 9, pp. 635642, 2015.

[12] W. A. Kadhim, M. J. Kadhim, and I. H. Hameed, "Antibacterial activity of several plant extracts against Proteus species," International Journal of Pharmaceutical and Clinical Research, vol. 8, no. 12, pp. 1673-1684, 2016.

[13] P. J. Barnes, "Inhaled corticosteroids," Pharmaceuticals, vol. 3, no. 3, pp. 514-540, 2010.

[14] N. A. Lipkovskaya, V. N. Barvinchenko, T. V. Fedyanina, and A. A. Rugal', "Physicochemical properties of quercetin and rutin in aqueous solutions of decamethoxin antiseptic drug," Russian Journal of Applied Chemistry, vol. 87, no. 1, pp. 36-41, 2014.

[15] A. Takos and F. Rook, "Towards a molecular understanding of the biosynthesis of Amaryllidaceae alkaloids in support of their expanding medical use," International Journal of Molecular Sciences, vol. 14, no. 6, pp. 11713-11741, 2013.

[16] S. Kumar and A. K. Pandey, "Chemistry and biological activities of flavonoids: an overview," The Scientific World Journal, vol. 2013, Article ID 162750, 16 pages, 2013.

[17] P. Maher, "The potential of flavonoids for the treatment of neurodegenerative diseases," International Journal of Molecular Sciences, vol. 20, no. 3056, pp. 1-19, 2019.

[18] A. N. Panche, A. D. Diwan, and S. R. Chandra, "Flavonoids: an overview," Journal of Nutritional Science, vol. 5, no. e47, pp. 1-15, 2016.

[19] S. I. Umar, B. Lawal, B. Alkali et al., "Antioxidant and antimicrobial activities of naturally occurring flavonoids from M. heterophylla and the safety evaluation in Wistar rats," Iranian Journal of Toxicology, vol. 13, no. 4, pp. 39-44, 2019.

[20] M. Hemshekhar, K. Sunitha, M. S. Santhosh et al., "An overview on genus Garcinia: phytochemical and therapeutical aspects," Phytochemistry Reviews, vol. 10, no. 3, pp. 325-351, 2011.

[21] T. K. Lim, Edible Medicinal and Non-edicinal Plants, vol. 2, Springer, Dordrecht, Netherlands.

[22] Z. Dahlan, L. Hanum, and E. Zahar, "Exploration and study of the diversity of Garcinia L. based on the source of macromorphological evidence and its use for plant morphology 
lectures," Educational Forum, vol. 28, no. 2, pp. 164-172, 2009, in Indonesian.

[23] K. Shadab, P. Anjum, and K. S. Bhise, "Antioxidant activity of pomegranate peel powder," Journal of Drug Delivery and Therapeutics, vol. 7, no. 2, pp. 81-84, 2017.

[24] U. A. Khan, H. Rahman, Z. Niaz et al., "Antibacterial activity of some medicinal plants against selected human pathogenic bacteria," European Journal of Microbiology and Immunology, vol. 3, no. 4, pp. 272-274, 2013.

[25] M. C. Ngule and H. M. Ndiku, "Antidiarrheal activity of Tetradenia riparia and Wubergia ugandensis ethnobotanical plants in Kenya," World Journal of Pharmaceutical Sciences, vol. 2, no. 10, pp. 1180-1183, 2014.

[26] A. A. Mostafa, A. A. Al-askar, K. S. Almaary, T. M. Dawoud, E. N. Sholkamy, and M. M. Bakri, "Antimicrobial activity of some plant extracts against bacterial strains causing food poisoning diseases," Saudi Journal of Biological Sciences, vol. 25, no. 2, pp. 361-366, 2018.

[27] A. S. Madhuri and R. Mohanvelu, "Evaluation of antidiabetic activity of aqueous extract of Mangifera indica leaves in alloxan induced diabetic rats," Biomedical \& Pharmacology Journal, vol. 10, no. 2, pp. 1029-1035, 2017.

[28] R. Islam, M. A. S. Khan, M. S. Islam, S. Benozir, and M. J. Alam, "Anti-diabetic properties of Lannea coromandelica L. bark extract on alloxan induced type-2 diabetic rats," European Journal of Pharmaceutical and Medical Research, vol. 5, no. 9, pp. 31-38, 2018.

[29] W. E. Grizzle, "Models of fixation and tissue processing," Biotech Histochem, vol. 84, no. 5, pp. 185-193, 2010.

[30] V. S. Gontijo, T. C. de Souza, I. A. Rosa et al., "Isolation and evaluation of the antioxidant activity of phenolic constituents of the Garcinia brasiliensis epicarp," Food Chemistry, vol. 132, no. 3, pp. 1230-1235, 2012.

[31] S. Hammami, H. Jannet, A. Bergaoui, L. Ciavatta, G. Cimino, and Z. Mighri, "Isolation and structure elucidation of a flavanone, a flavanone glycoside and vomifoliol from Echiochilon fruticosum growing in Tunisia," Molecules, vol. 9, no. 7, pp. 602-608, 2004.

[32] A. Shafaghat and F. Salimi, "Extraction and determining of chemical structure of flavonoids in Tanacetum parthenium (L.) Schultz. Bip. from Iran," Journal of Sciences Islamic Azad University, vol. 18, no. 68, pp. 39-42, 2008.

[33] C. A. D. Andrade, J. L. D. S. Carvalho, M. M. Cunico et al., "Antioxidant and antibacterial activity of extracts, fractions and isolated substances from the flowers of Acacia podalyriifolia A," Brazilian Journal of Pharmaceutical Sciences, vol. 46, no. 4, pp. 715-722, 2010.

[34] R. Álvarez-Álvarez, A. Botas, S. M. Albillos et al., "Molecular genetics of naringenin biosynthesis, a typical plant secondary metabolite produced by Streptomyces clavuligerus," Microbial Cell Factories, vol. 14, no. 178, pp. 1-12, 2015.

[35] A. Esmaeli, Z. Mousavi, M. Shokrollahi, and A. Shafagat, "Antioxidant activity and isolation of luteolin from Centaurea behen L. Grown in Iran," Journal of Chemistry, vol. 2013, Article ID 620305, 5 pages, 2013.

[36] O. J. Ode and I. U. Asuzu, "Luteolin isolate from the methanol extract identified as the single-carbon compound responsible for broad antiulcer activities of Cassia singueana Leaves," IOSR Journal Of Pharmacy, vol. 4, no. 10, pp. 17-23, 2014.

[37] C. G. Karanjgaokar, P. V. Radhakrishnan, and K. Venkataraman, "Morelloflavone, a 3-(8-) flavonylflavanone, from the heartwood of," Tetrahedron Letters, vol. 8, no. 33, pp. 3195-3198, 1967.
[38] C. Fa-Ching, Y.-M. Lin, L. Yuh-Meei, and H. Jeng-Ching, "Phenolic compounds from the heartwood of Garcinia multiflora," Phytochemistry, vol. 14, no. 1, pp. 300-303, 1975.

[39] P. G. Waterman and E. G. Crichton, "Xanthones and biflavonoids from Garcinia densivenia stem bark," Phytochemistry, vol. 19, no. 12, pp. 2723-2726, 1980.

[40] X.-C. Li, A. S. Joshi, B. Tan, and B. Tan, "Absolute configuration, conformation, and chiral properties of flavanone$\left(3 \longrightarrow 8^{\prime \prime}\right)$-flavone biflavonoids from Rheedia acuminata," Tetrahedron, vol. 58, no. 43, pp. 8709-8717, 2002.

[41] T. Masuda, D. Yamashita, Y. Takeda, and S. Yonemori, "Screening for tyrosinase inhibitors among extracts of seashore plants and identification of potent inhibitors fromGarcinia subelliptica," Bioscience, Biotechnology, and Biochemistry, vol. 69, no. 1, pp. 197-201, 2005.

[42] W. M. N. H. W. Salleh, N. S. A. N. Sazali, F. Ahmad, and M. Taher, "Biflavonoids from the leaves and stem bark of Garcinia griffithii and their biological activities," Marmara Pharmaceutical Journal, vol. 21, no. 4, pp. 889-897, 2017.

[43] G. A. Herbin, B. Jackson, H. D. Locksley, F. Scheinmann, and W. A. Wolstenholme, "The biflavonoids of Garcinia volkensii (Guttiferae)," Phytochemistry, vol. 9, no. 1, pp. 221-226, 1970.

[44] H. Duddeck, G. Snatzke, and S. S. Yemul, "13C NMR and CD of some 3,8" -biflavanoids from Garcinia species and of related flavanones," Phytochemistry, vol. 17, no. 8, pp. 1369-1373, 1978.

[45] T. Soderberg, Organic Chemistry with a Biological Emphasis, Vol. 1, Chemistry Publication University of Minnesota Morris Digital Well, vol.1, Morris, Minnesota, 2019.

[46] H. A. Shaban, H. S. Ali, G. F. Bareh, A. R. S. Al-khalifa, and M. M. Amer, "Antimicrobial activity of two polysaccharide edible films incorporated with essential oils against three pathogenic bacteria," Journal of Applied Sciences, vol. 17, no. 4, pp. 171-183, 2017.

[47] Y. Xie, W. Yang, F. Tang, X. Chen, and L. Ren, “Antibacterial activities of flavonoids: structure-activity relationship and mechanism," Current Medicinal Chemistry, vol. 22, no. 1, pp. 132-149, 2015.

[48] R. Purnamasari, D. Winarni, A. A. Permanasari et al., "Anticancer cctivity of methanol extract of Ficus carica leaves and fruits against proliferation, apoptosis, and necrosis in Huh7it cells," Cancer Informatics, vol. 18, pp. 1-7, 2019.

[49] L. Cazarolli, L. Zanatta, E. Alberton et al., "Flavonoids: prospective drug candidates," Mini-Reviews in Medicinal Chemistry, vol. 8, no. 13, pp. 1429-1440, 2008.

[50] W. D. Fitriana, T. Ersam, K. Shimizu, and S. Fatmawati, "Antioxidant activity of Moringa oleifera extracts," Indonesian Journal of Chemistry, vol. 16, no. 3, pp. 297-301, 2016.

[51] A. C. R. Rana and B. Gulliya, "Chemistry and pharmacology of flavonoids- a review," Indian Journal of Pharmaceutical Education and Research, vol. 53, no. 1, pp. 8-20, 2019.

[52] C.-H. Leung and C.-P. Liu, "Diabetic status and the relationship of blood glucose to mortality in adults with carbapenem-resistant Acinetobacter baumannii complex bacteremia," Journal of Microbiology, Immunology and Infection, vol. 52, no. 4, pp. 654-662, 2019.

[53] M. N. Sarian, Q. U. Ahmed, S. Z. Mat So'ad et al., “Antioxidant and antidiabetic effects of flavonoids: a structureactivity relationship based study," BioMed Research International, vol. 2017, Article ID 8386065, 14 pages, 2017.

[54] R. K. Al-Ishaq, M. Abotaleb, P. Kubatka, K. Kajo, and D. Büsselberg, "Flavonoids and their anti-diabetic effects: cellular mechanisms and effects to improve blood sugar levels," Biomolecules, vol. 9, no. 430, pp. 1-35, 2019. 
[55] R. Vinayagam and B. Xu, "Antidiabetic properties of dietary flavonoids: a cellular mechanism review," Nutrition \& Metabolism, vol. 12, no. 60, pp. 1-20, 2015.

[56] A. K. Hassan, D. A. El-kotby, M. M. Tawfik, R. E. Badr, and I. M. Bahgat, "Antidiabetic effect of the Egyptian honey bee (Apis mellifera) venom in alloxan-induced diabetic rats," The Journal of Basic and Applied Zoology, vol. 80, no. 58, pp. 1-9, 2019.

[57] A. Mitrakou, "Kidney: its impact on glucose homeostasis and hormonal regulation," Diabetes Research Clinical Practice, vol. 935, pp. 566-572, 2011.

[58] A. Mather and C. Pollock, "Glucose handling by the kidney," Kidney International, vol. 79, no. suppl 120, pp. S1-S6, 2011.

[59] L. Bai, X. Li, L. He et al., "Antidiabetic potential of flavonoids from traditional Chinese medicine: a review," The American Journal of Chinese Medicine, vol. 47, no. 5, pp. 933-957, 2019.

[60] T. Senoner, S. Schindler, S. Stättner, D. Öfner, J. Troppmair, and F. Primavesi, "Associations of oxidative stress and postoperative outcome in liver surgery with an outlook to future potential therapeutic options," Oxidative Medicine and Cellular Longevity, vol. 2019, Article ID 3950818, 18 pages, 2019. 